\title{
Impact of Implementation Energy Efficient Appliances in Palestinian Market
}

\author{
Imad Ibrik ${ }^{*}$, Tahseen Sulaiman ${ }^{2}$ \\ ${ }^{1}$ An-Najah National University, Energy Research Center, Nablus, Palestine \\ ${ }^{2}$ Technical Services Deparment, Palestine Standards Institution, Ramallah, Palestine \\ Email: ‘iibrik@najah.edu
}

How to cite this paper: Ibrik, I. and Sulaiman, T. (2019) Impact of Implementation Energy Efficient Appliances in Palestinian Market. Open Journal of Energy Efficiency, 8, 149-165.

https://doi.org/10.4236/ojee.2019.84009

Received: September 3, 2019

Accepted: November 4, 2019

Published: November 7, 2019

Copyright (c) 2019 by author(s) and Scientific Research Publishing Inc. This work is licensed under the Creative Commons Attribution International License (CC BY 4.0).

http://creativecommons.org/licenses/by/4.0/

(c) (i) Open Access

\begin{abstract}
Recently, Palestine has been willing to improve its energy efficiency action plan and policies. As the Electrical demand for energy is increasing in Palestine, improving energy efficiency can be considered as an efficient way to achieve reductions in energy consumptions. In this respect, energy efficiency action plan and its strategies must be designed to overcome existing market barriers against using energy efficient appliances in residential and commercial sectors in Palestine. This study provides background on the benefits of stakeholders and steps needed to support energy efficiency standards and labeling in Palestine. Furthermore, this study attempts to predict the techno-economic impact of implementing high efficient electrical appliances in Palestine. Survey-based analyses from 300 households were conducted in 2019 to estimate residential sector electrical appliances usage, behavior and their knowledge in electrical appliances labels and standards, the study aims also to estimate the perception and willingness of Palestinian householders to shift towards more energy efficient choices. The study will focus on 8 electrical appliances that constitute a major share of the electricity used within households and commercial sectors in Palestinian market.
\end{abstract}

\section{Keywords}

Energy Efficiency, Standards \& Labels, Electrical Appliances

\section{Introduction}

This Energy efficiency standards and labels (EE S\&L) are sets of procedures and regulations that, respectively, prescribe the minimum energy performance of manufactured products and the informative labels on these indicating products' energy performance [1]. They are meant to help the market recognize energy efficiency and act on it. Without the information provided by labels, consumers 
and other end-users are often unable to make an informed decision about the true cost of a product, and manufacturers lack the incentive to improve the energy performance of it as there is no way for the market to recognize and value this aspect. Standards can be set to ensure that obsolete and inefficient technology does not continue to dominate the market, much more effectively than is possible by the actions of individual end-users [2].

Consumers in Palestine like in other countries are often inclined to buy the cheapest product on the market. This burdens them with much higher running cost for years to come, and countries with the need to invest much more in energy supply networks than would be needed if all products would comply with minimum energy performance requirements. Neither one customer nor one manufacturer alone can alter this situation. Governments, however, with technical support, can implement standards and labelling programmes that protect the population from such expensive "cheap products", at a limited cost, and protect manufacturers of highly efficient products from competitors saturating the market with these expensive "cheap products" [3].

Standards and labels work best as a part of a holistic market transformation strategy [4]. Standards ensure that the worst performing products are removed from the market, while labels encourage consumers to purchase increasingly more efficient products. These can be further supported by direct incentives to support the introduction of leading-edge products through R\&D support, subsidies, procurement, etc.

Palestine, with the highest electricity prices in the region, has made a good start by adopting its first national energy efficiency action plan NEEAP [3], the aim of the plan is to achieve the indicative target of $5 \%$ less electricity consumption in 2020 adopted in the Energy National Strategy. And by establishing a revolving fund for financing EE projects [5] [6] [7]. It should continue developing its regulatory framework and further explore options to use high efficient appliances in the market.

In Palestine, the electrical energy consumption in the residential sector is at the highest levels compared to the industrial and commercial sectors. The percentage of energy consumption in various sectors is $57 \%$ for residential, $6 \%$ for industrial, $18 \%$ for commercial and public services, and $1 \%$ for agriculture as shown in Figure 1 [3].

Recently, Palestine is attempting to improve its energy efficiency policies. As the demand for energy is increasing in Palestine, improving energy efficiency can be considered as an efficient way to achieve its sustainable development goals [8]. In this respect, government policies and program strategies must be designed to overcome persistent market barriers against energy efficient household appliances. Label and standard programs can be used as a strategy to improve energy efficient products. The aim of this paper is to provide a broad overview of appliance efficiency standards and labeling programs in Palestine. The paper deals with the estimation of the perception and willingness of Palestinian householders to shift towards more energy efficient choices, legal issues related 


\section{Total (GWh)}

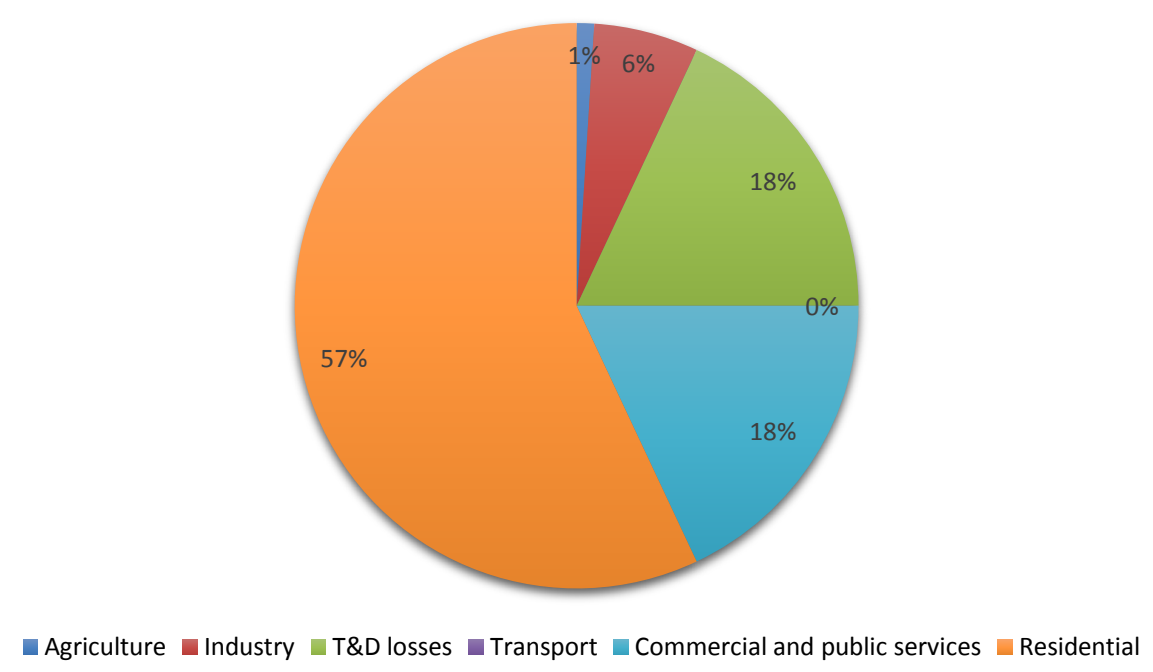

Figure 1. Electrical energy consumption in Palestine per sector.

to energy efficiency will be discussed and the current situation and challenges related to labeling appliances will be analyzed.

Also, this paper will present the potential of implementing standards and labels on annual saving of electricity from different appliances in the residential sector according to field survey conducted in different cities in West Bank. The impact of implementing high efficient appliances will investigate and expect significant impact on electricity consumption in Palestine. Furthermore, a feasibility of implementing high efficient appliances and its environmental impact will be conducted.

\section{Literature Review}

The energy labels have been adopted by more than 90 countries in the world covering different appliances and equipment's in the commercial, industrial and residential sectors. The energy efficiency of major appliances has improved at an average rate of $3 \%-4 \%$ annually as compared to the rate of technology improvement between 0.5 - 1 percent annually. A trend of decline in long-term appliance purchase prices has been observed despite increase in energy efficiency (IEA, 2015) [9].

A number of studies have been published in this context, Özge Kama (2013) [10] provided a broad overview of current labeling and standard programs for Turkey and selected case countries. By doing so, we aim to present the extent of the coverage and the different methods used in such efficiency programs implemented in different countries. Alwiyah Abd Alfattah and others (2017) [11] concentrated on cold electrical appliances because it was found that cold appliances are about $32.7 \%$ of total household electrical energy consumption in Jordan. Four scenarios for replacing the old appliances have been suggested and analyzed. It was found that the net saving from 2011 to 2020 will be approx- 
imately $4451.17 \mathrm{GWh}$. The associated $\mathrm{CO}_{2}$ emission reduction during the 10 years is expected to reach 2,221,000 tons.

Abu Saleh Ahmed and others (2011) [12] conducted a series of experiment investigations on six clothes washers of varying capacities. The objectives are to develop the standards and labels.

Human life and his needs depend totally on electricity and this need can be in many forms and using household electrical appliances is one of these forms, in these days human need electrical appliances for transport, cooking, cooling and freezing food, cooling and heating spaces, clothes cleaning and ironing, houses cleaning, and entertainment [10].

In spite of technological innovations a decrease in electrical demand occurred but still substitute for electricity, therefore many countries started care as a priority about energy efficiency which improving it means doing the same activity or service with less energy consumed and the starting point of this improvement is the technical directives and standards and developing these directives and standards will lead to energy conservation and lowering the emitted to atmosphere.

In South Africa, for example, there are 9 million of electric ovens are in use and each consumes $702 \mathrm{kWh} /$ year, and this result in total consumption of 6.3 TWh and the big transformation in energy efficiency will be achieved if old ovens are replaced by new ovens with the new technology [13].

In Figure 2, we can see the expected energy consumption difference when comparing the efficient scenario B with ordinary scenario.

From Figure 2, we can simply realize that in the year 2030 approximately the conserved electrical energy as a result of efficiency increased and in spite of stock increase will be $31 \%$ which approximately about $2.7 \mathrm{TWh}$, and also the environment will be protected from $1.82 \mathrm{Mt}$ of $\mathrm{CO}_{2}$ to atmosphere [13].

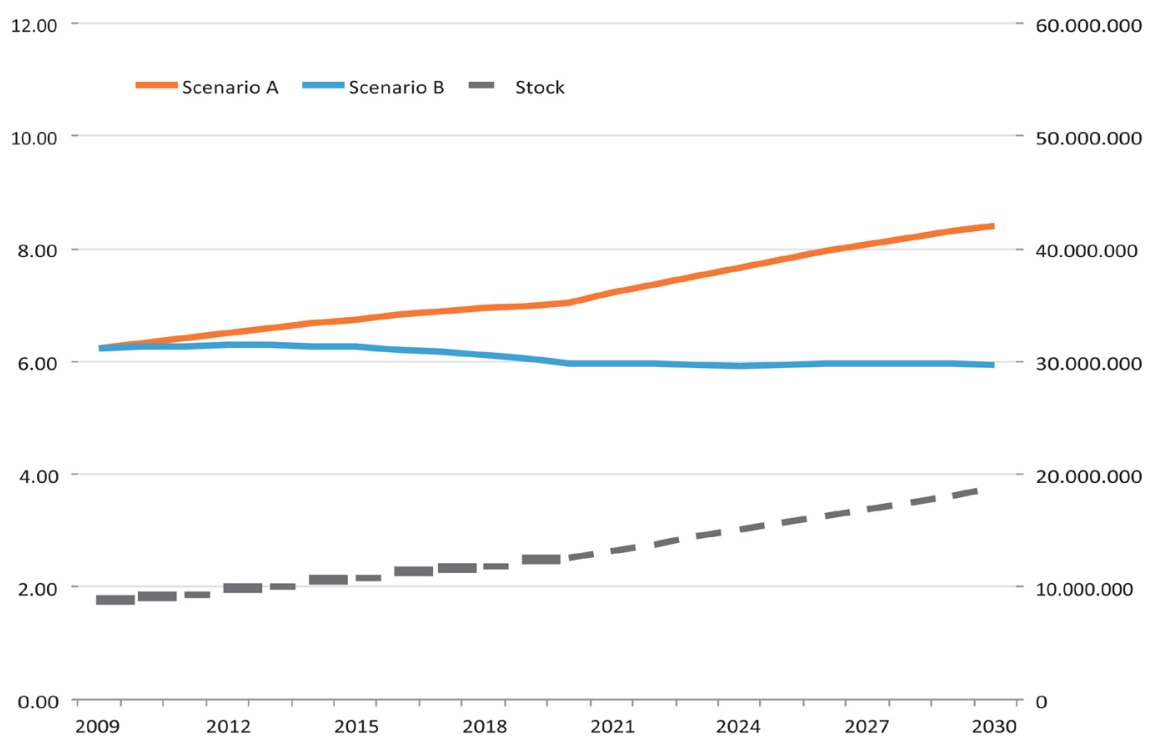

Figure 2. Electricity consumption Ovens, Baseline Scenario (A) vs. Efficiency Scenario (B). Source: Wuppertal Institute (2015). 
Electrical appliances energy efficiency in most countries is priority in these days to lower the energy consumption and to conserve environment by lowering emitted gases to atmosphere [14].

Energy classification label of electrical appliances in some countries is mandatory and voluntary in other, and this label divided into two types, the first is endorsement label which indicates that this appliance belongs to most efficient category, the second is the comparative label and this type of label contains the important energy consumption information to give the consumer the ability to judge between the appliances in the same category and to take the proper buy decision accordingly, this label contains scale or indicator like 1, 2, 3 or 1 star, 2 stars, 3 stars or A, B, C, and both types of labels can coexist on the same appliance [14].

In 1992, the EU adopted the Energy Labeling Directive for household appliances. It compelled retailers to display a label to consumers. The label rated the energy efficiency of these appliances on a scale ranging from energy class A (most efficient) to energy class G (least efficient). The message was reinforced through an easy color coding, ranging from dark green for the most efficient class to red for the most inefficient class [14].

The EU comparative energy label is simple and clear for consumers to perform a full judgment between appliances and to buy the most efficient appliances, this label covers many types of appliances in EU like cooking, heating, TV's, washing machine, and dishwashers [14].

In 2003 the EU opened the new opportunity for improving energy efficiency by letting the manufacturers to mark $\mathrm{A}+$ and $\mathrm{A}++$ but the positive sign negatively affect and weaken the market [15].

Many countries working on the efficiency programs of appliances to achieve energy conservation and one of these programs as detailed in Jerusalem post that Israeli ministry of energy and water will replace 10,000 units of old air conditioners that have been in use for 10 years and more and they expect this program to assist in energy conservation by 17 million $\mathrm{kWh} /$ year, and they invested 2.85 million $\$$ in this program that the government will cover $40 \%$ of the appliance cost, transport, and installation of these appliances for the households who receive social security [16].

This program is one of many programs that will extend to replace old refrigerators and fluorescent light bulbs and these programs expected to save and conserve $1700 \mathrm{kWh} /$ year for each type replacement and 228 - 242\$ saving/year for each appliance replacement [16].

\section{Methodology of Analysis}

Statistics of imported electrical appliances, its energy classification and its quantities to Palestine are very weak as a result of non-control Palestinian government ministries on the boarders and the available records are general and partially. 
Survey-based analyses were conducted on 2019 to estimate these data, and to study the urban residential energy and usage behavior. A total of 300 Palestinian households participated in the survey, answering questions about their family conservation behaviors, and reactions to specific energy conservation policies, electrical appliances labels and standards. The analysis was based on asking the households about the main appliances they have and did they buy it new or old, also about the energy label of these appliances and about the meaning of these labels.

The survey took the form of quantitative interviews and was carried out among target respondents using a face-to-face and online technique. Representativeness of the sample was ensured throughout the sampling process. Random sampling was used to select the respondents to include in this study.

\section{Results of Survey}

The results of survey regarding general information about used appliances in Palestine summarized in Table 1.

The results of survey regarding different appliances used in Palestinian market, was as the following:

1) Split Air conditioner

The demand increased on the split air conditioner in the last 15 years, as a result of climate changes, so the temperature and relative humidity are higher than the past and it reaches $40^{\circ} \mathrm{C}$ and $90 \%$ respectively. In some Palestinian areas, the new and famous trademarks of air conditioner still costly and a sector of people still can't own it so they buy the old one as its lower cost, (delete this sentences) Figure 3 shows that $79.8 \%$ of people from the beginning they purchased a new A/C comparing with $21.2 \%$ purchased old A/C.

Concerning awareness of people regarding energy classification label on Air conditions, the results illustrated in Figure 4.

According to the figure, we can summarize that high percentage of Palestinian

Table 1. General questions regarding the used appliances.

\begin{tabular}{lc}
\hline \multicolumn{1}{c}{ Question details } & \% of household positively answer \\
\hline $\begin{array}{l}\text { Knowing the details and have the ability to read the energy } \\
\text { classification label }\end{array}$ & $42.5 \%$ \\
Watched, read literature about electrical appliances label & $22.5 \%$ \\
classification & $72.5 \%$ \\
$\begin{array}{l}\text { Knowing the difference between the H. efficient and low efficient } \\
\text { appliances }\end{array}$ & $47.5 \%$ \\
$\begin{array}{l}\text { Ready to pay 15\% - 25\% more to buy H. efficient appliance } \\
\text { instead of low efficient one }\end{array}$ & $85 \%$ \\
$\begin{array}{l}\text { Have a doubt about the energy label on the existed appliances in } \\
\text { the market }\end{array}$ & $41 \%$ \\
$\begin{array}{l}\text { Reading the energy labels before purchasing electrical appliances } \\
\text { Purchasing electrical appliances that are without labels }\end{array}$ & $52 \%$ \\
\hline
\end{tabular}




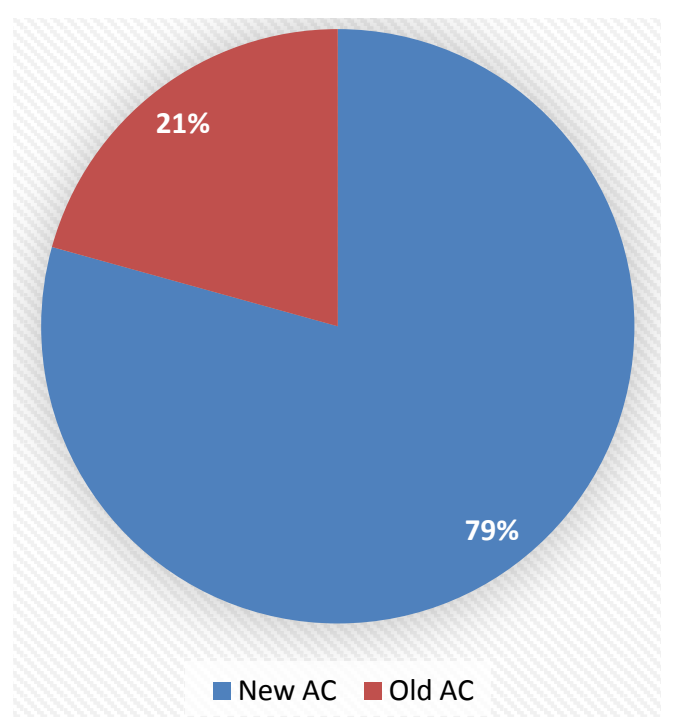

Figure 3. Percentage of people used new or old A/C.

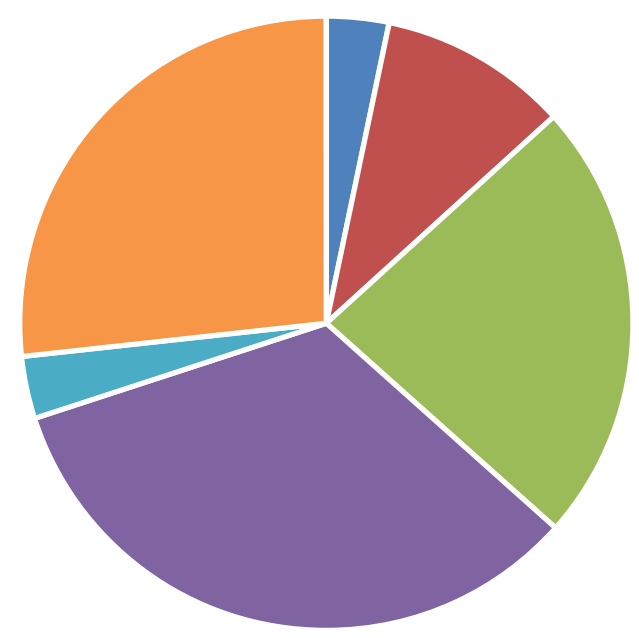

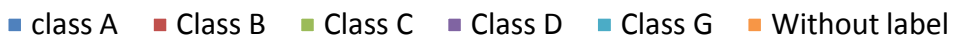

Figure 4. Percentage of energy label used for Split Air conditioner.

people $27 \%$ bought $\mathrm{A} / \mathrm{C}$ not depends on energy classification label, in addition, $34 \%$ of selected people using class D of A/C, which is standard efficient.

\section{2) Refrigerators}

This appliance is essential and basic in almost every house of Palestinian people, Figure 5 shows that $98 \%$ of people purchased a new refrigerator from the beginning.

Concerning awareness of people about energy classification label, the results shown in Figure 6.

Most of people are prefer to pay lower initial price than to have high efficient refrigerator.

3) Washing Machines

The results are shown in Figure 7. 


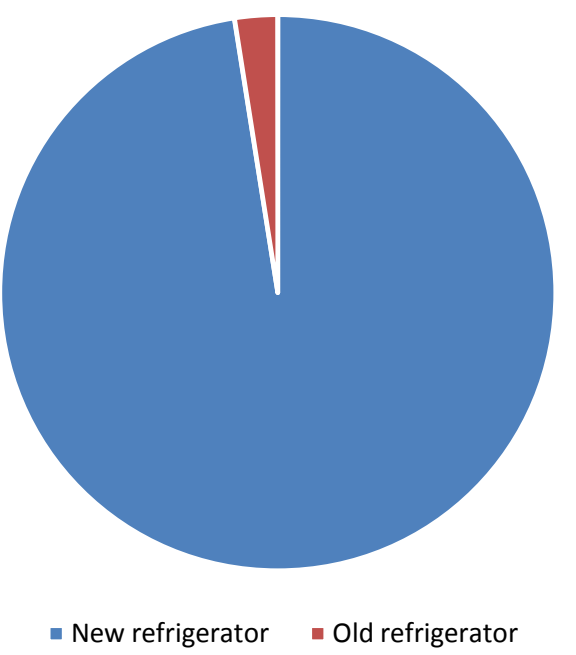

Figure 5. Percentage of people purchased a new and old refrigerator.

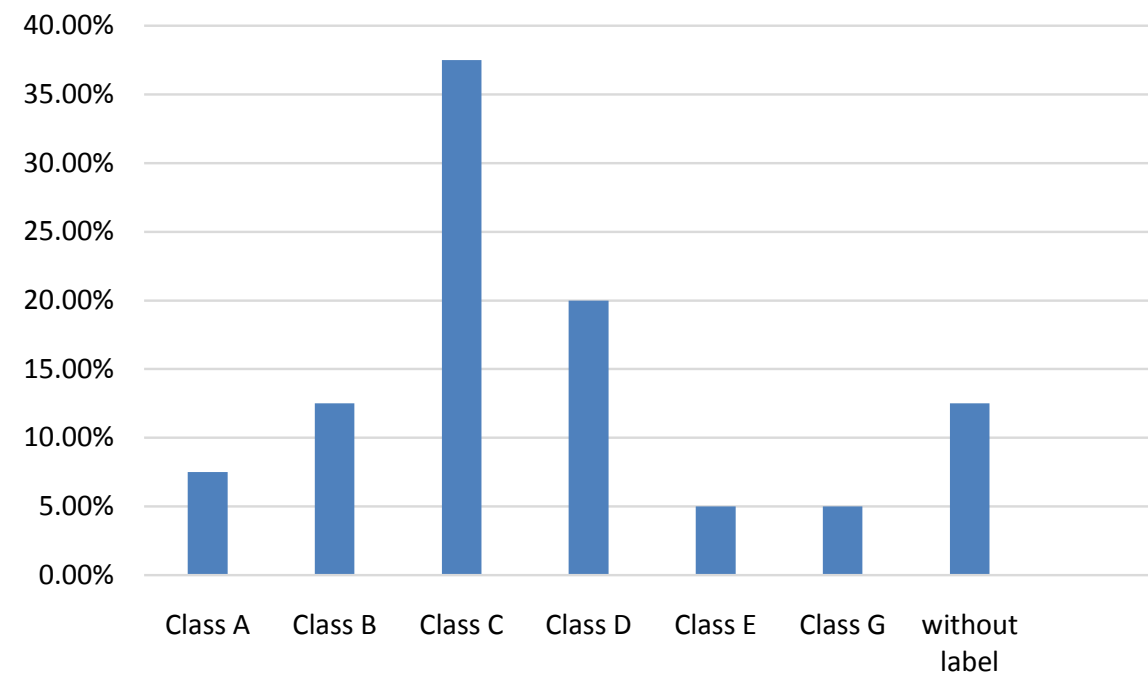

Figure 6. The results of energy label used in Palestinian market for refrigerators.

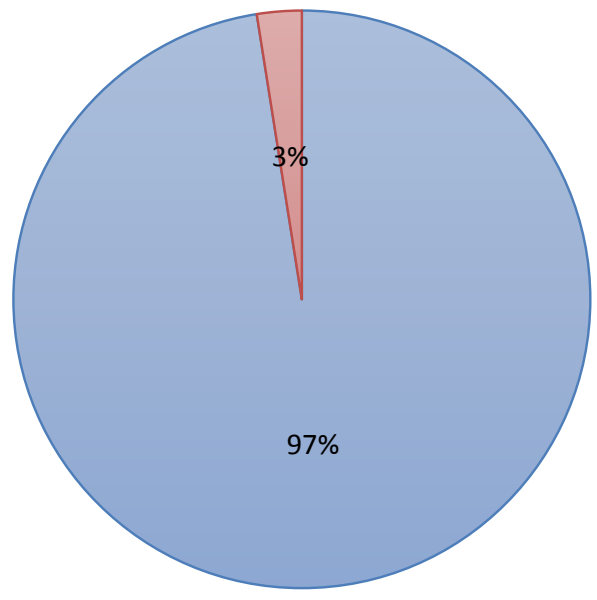

$\square$ New W. machine $\quad \square$ Old W.machine

Figure 7. Percentage of using new and old washing machine. 
The data collected about the energy label used for washing machine, the results are shown in Figure 8.

4) Food Freezers

The data collected from the performed survey show that $17.5 \%$ of houses have separate food freezer, and $57 \%$ of them purchased a new appliance as shown in Figure 9.

Concerning energy label classification it can be illustrated in Figure 10.

5) Clothes Dryer

The results of survey show that $47.5 \%$ of houses have clothes dryer, and people prefer to purchase a new appliance as illustrated in Figure 11.

6) Dish Washer

Only $7.5 \%$ of the questioned people have a new dish washer appliance, and the results of survey regarding energy label are shown in Figure 12.

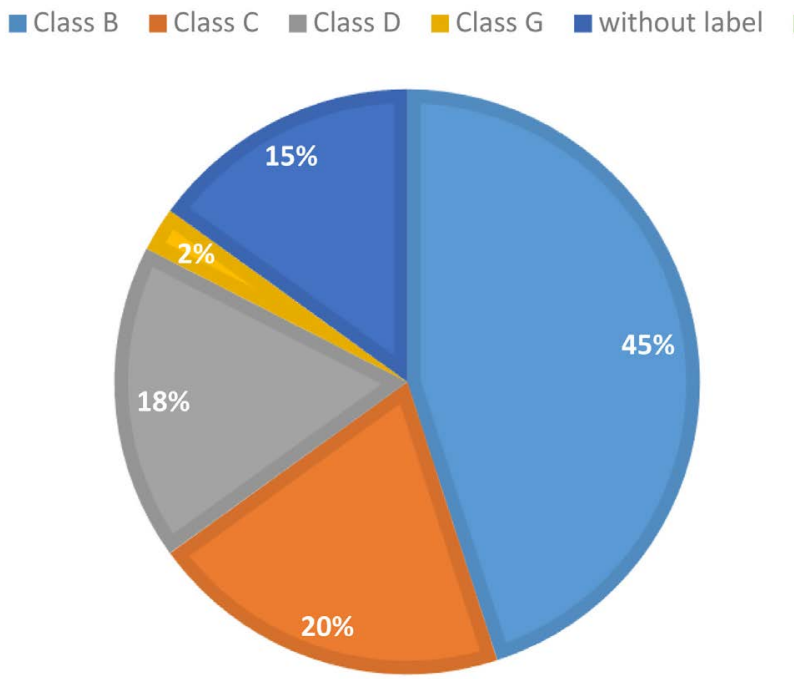

Figure 8. Existing energy labels in Palestinian market for washing machine appliance.

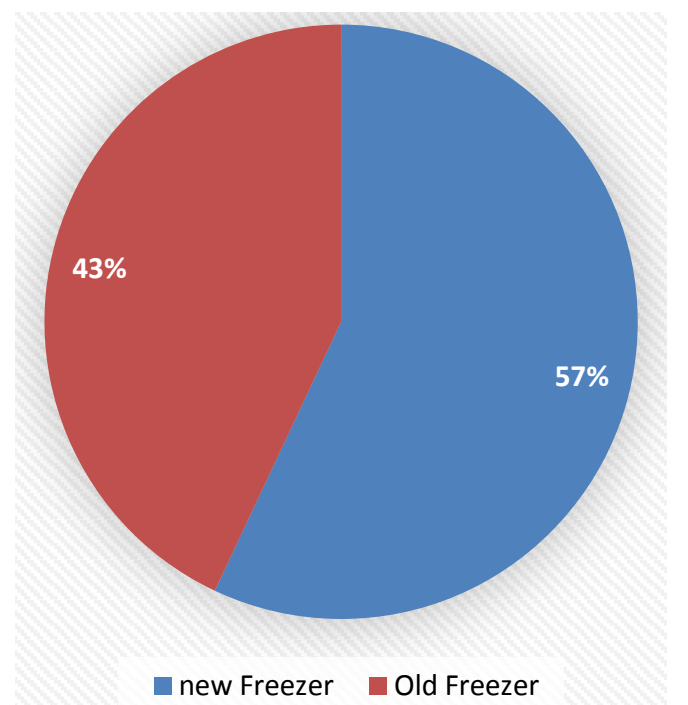

Figure 9. Percentage of purchasing new or old freezer. 


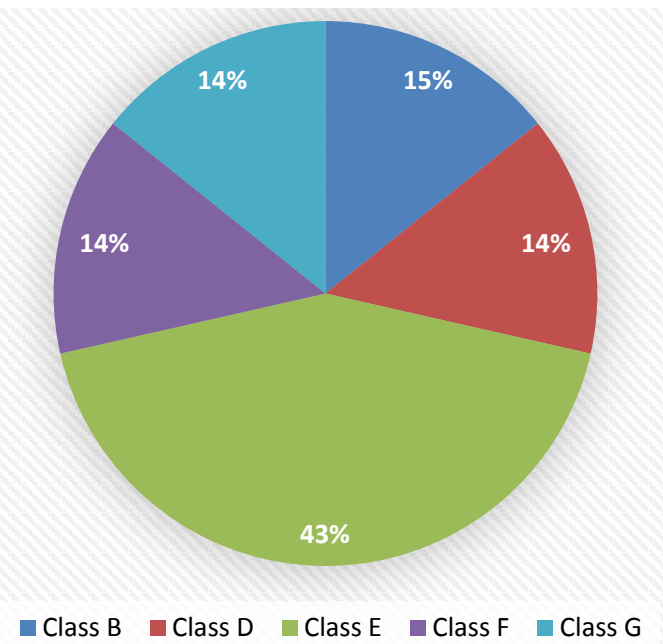

Figure 10. Percentage of using different energy label for food freezer.

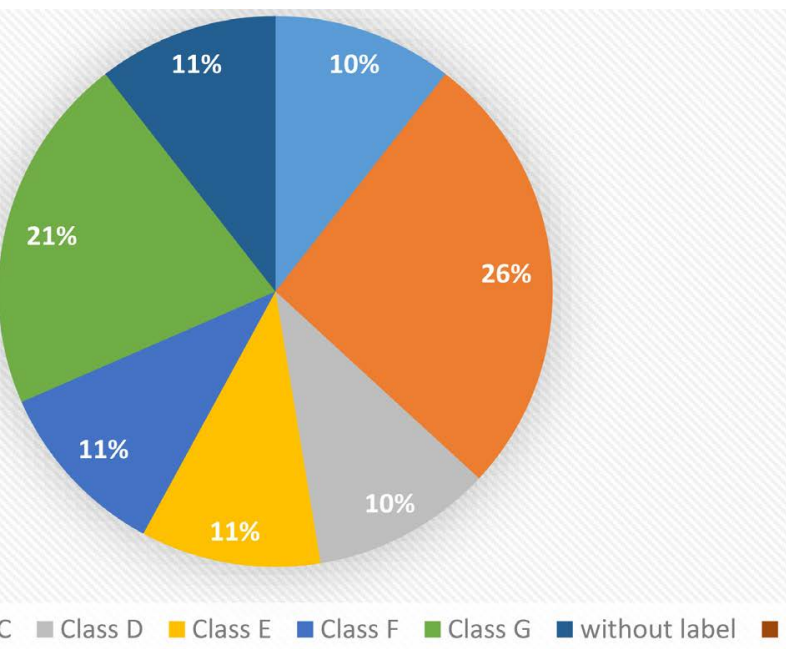

Figure 11. Percentage of using different energy labels in clothes dryer.

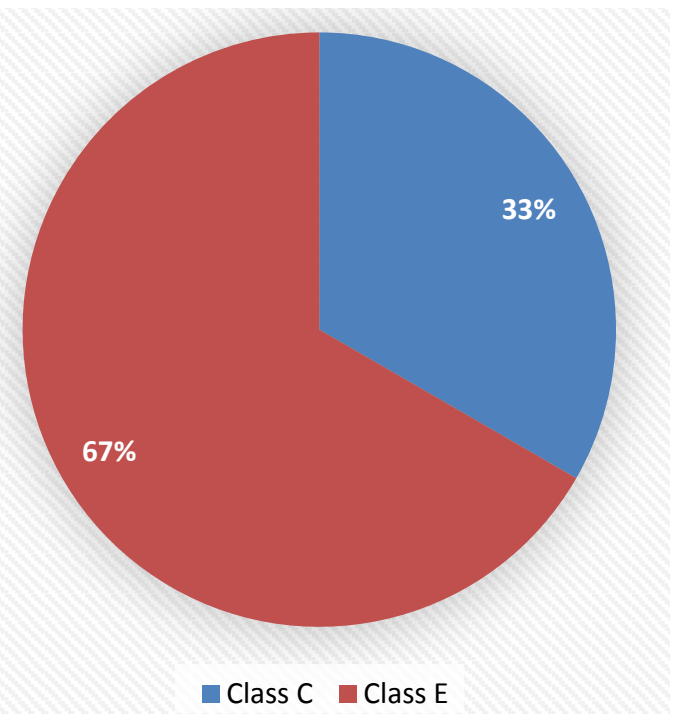

Figure 12. Percentage of using different energy labels in dish washer appliance. 


\section{7) Electrical Oven}

In Palestinian houses around $87.5 \%$ have electrical oven, and Figure 13 shows the energy label used.

8) Microwave Oven

Most of Palestinian houses, around $97.5 \%$ have microwave oven, the results of survey regarding energy labels are shown in Figure 14.

\section{Labeling of Electrical Appliances in Palestine: Current Situation and Challenges}

The electrical household appliances in Palestine are mainly imported from world countries and a small percentage and new industrial sectors are opened, Palestine area is under the occupation and since the coming of Palestine national authority its main goal is to support the people on the ground and to achieve their

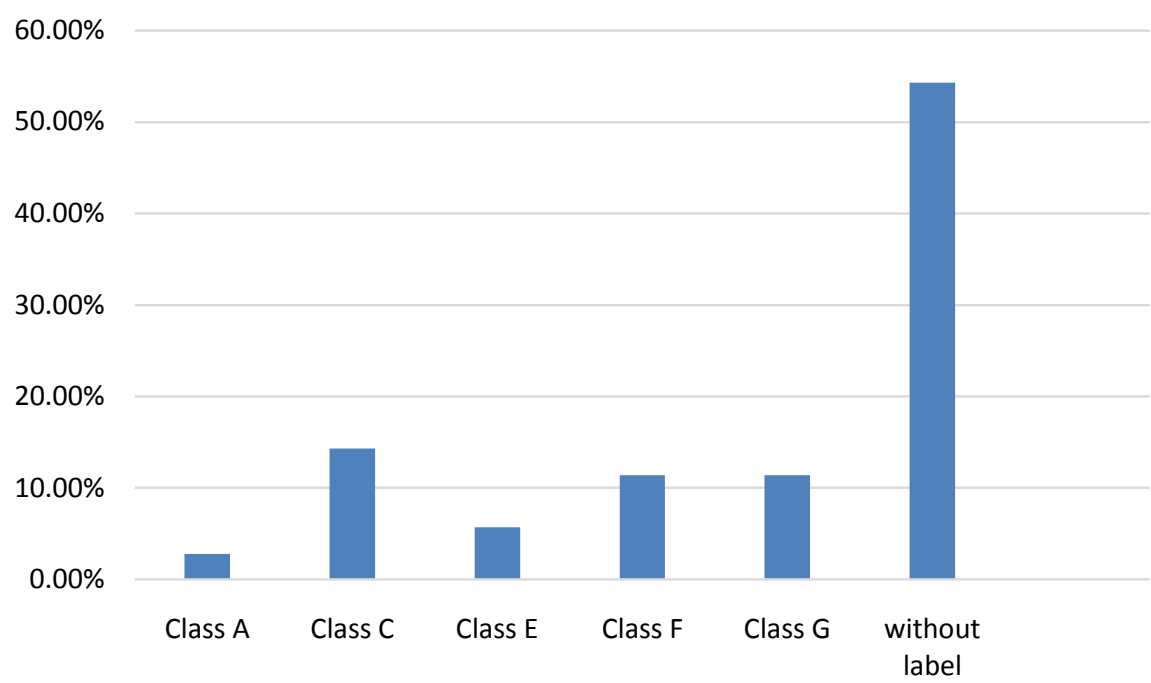

Figure 13. Percentage of using different energy labels in electrical oven.

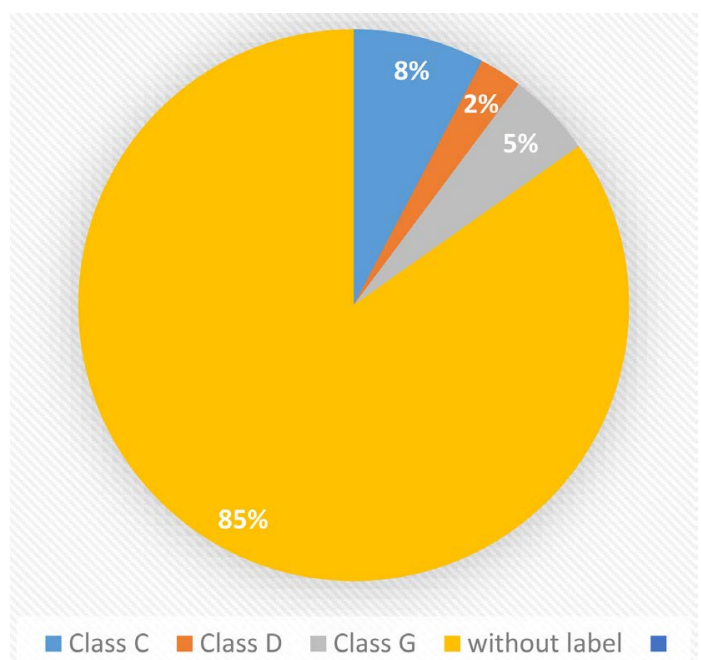

Figure 14. Percentage of using different energy labels for microwave oven in Palestinian market. 
safety, Palestine standards institute is the body who responsible on legislating the standards and the technical regulations and its priority since the beginning is to legislate the technical directives and standards for the people safety, the energy calcification label and its related standards still voluntary, recently PSI working on preparing the technical directive for the electrical appliances energy label calcification but still not approved and published.

Palestine national authority responsible ministries haven't any control on the boarders to regulate the import products to Palestine and the expired Paris protocol gave Israeli government's ministries the authority to regulate and to control this process [17]. While also its important to mention that the Israeli authorities don't restraints the transfer and trade of products from Israel areas to Palestine area so the Israeli manufactured products, and its famous for Palestinian the appliances statement (group B) which mostly factory defect or lower quality products and the used products there, are easy to be sold in the Palestine area and these activities are well known and people demand it because of its competitive price in comparison with the new appliances and some of these appliances are dumping the market like the used split air conditioner and others, this type of appliances deeply affect the residential and commercial energy consumption and its actually harm the consumer wallet instead of saving.

\section{Impact of Utilization High Efficient Electrical Appliances}

After Palestinian looking for lower price appliances and according to the performed study there are also factors can affect the Palestine consumer purchase decision like almost no guiding brochures, educating literatures, and Video \& audio programs in broadcast and radio stations to educate and guide the Palestine consumer of H.E appliances advantages on his pocket and on the electrical energy stability on the national level instead of standard efficient or least efficient appliances disadvantages on his pocket firstly and then its bad effects on the grid and national electrical energy stability in spite of its lower price in comparison with H.E appliances, in addition study results of high doubts of the consumers on the stickered energy label truth and its effect on the energy consumption and money saving from the electrical consumption bill.

The average electrical appliances initial cost as per the Palestinian market is indicated in Table 2.

\subsection{Energy Saving Impact}

Using high efficient electrical appliances will save a lot of consumed energy when compared to standard electrical appliances and this will positively affect the total energy houses bills and consumption.

Table 3 shows some electrical types and consumption according to energy label classification.

From Table 3, it's clear that a good reduction of energy consumption can be achieved by implementing H.E. Appliances in Palestinian market. 
Table 2. Comparison initial cost of some appliances types according to energy label.

\begin{tabular}{ccc}
\hline Appliance type & Energy label & Initial cost (\$) \\
\hline 8 Kg washing and spin machine & A & 562 \\
255 -liter refrigerator with 19 liters freezer up & D & 472 \\
home Vacuum cleaner & A & 437 \\
& D & 372 \\
12,000 Btu/hr split air conditioner & A & 100 \\
& D & 85 \\
16 liters microwave oven & A & 425 \\
40 liters built in electrical oven & D & 360 \\
& A & 162 \\
& D & 137 \\
& A & 687 \\
\hline
\end{tabular}

Table 3. Energy saving comparison when use H.E instead of standard appliances.

\begin{tabular}{cccc}
\hline Appliance & $\begin{array}{c}\text { Annual Energy } \\
\text { Consumption of Standard } \\
\text { Efficient appliance }\end{array}$ & $\begin{array}{c}\text { Annual Energy } \\
\text { consumption of using } \\
\text { H.E appliances }\end{array}$ & $\begin{array}{c}\text { Saving } \\
\mathrm{kWh} / \text { Year }\end{array}$ \\
\hline $\begin{array}{c}457.02 \mathrm{kWh} \\
\text { 8 Kg washing and spin machine }\end{array}$ & $24062.5 \mathrm{~L}$ & $234 \mathrm{kWh}$ & $223.02 \mathrm{kWh}$ \\
$\begin{array}{c}255 \text {-liter refrigerator with 19 liters } \\
\text { freezer up }\end{array}$ & $341.78 \mathrm{kWh}$ & $12320 \mathrm{~L}$ & $11742.5 \mathrm{~L}$ \\
home Vacuum cleaner & $83.97 \mathrm{kWh}$ & $43 \mathrm{kWh}$ & $184.78 \mathrm{kWh}$ \\
$\begin{array}{c}12,000 \text { Btu/hr split air conditioner } \\
16 \text { liters microwave oven }\end{array}$ & $1064.45 \mathrm{kWh}$ & $545 \mathrm{kWh}$ & $519.45 \mathrm{kWh}$ \\
40 liters built in electrical oven & $312.5 \mathrm{kWh}$ & $60 \mathrm{kWh}$ & $57.18 \mathrm{kWh}$ \\
\hline
\end{tabular}

\subsection{Economic Impact}

Conserving energy will economically affect the consumer bill, also effect on lowering the demands on the grid and this will also lower the electrical losses in electrical network. The H.E appliances are more expensive than standard appliances, therefore life cycle cost analysis should be determined. The extra cost for H.E. Appliances was calculated for some appliances in Palestinian market and it's shown in Table 4.

Table 5 shows the difference of consumption between H.E appliances and standard appliances and the annual saving.

The simple Payback Period (S.P.B.P) can be calculated to determine the feasibility of using H.E. appliances as in "Equation (1)".

$$
\text { S.P.B.P = Investment } / \text { Saving }
$$

According to Table 4 and Table 5, the S.P.B.P was calculated for different appliances and the results are shown in Table 6. 
Table 4. The needed extra investment to use H.E instead of standard appliances.

\begin{tabular}{cc}
\hline Appliance type & Extra cost (\$) \\
\hline 8 Kg washing and spin machine & 102.85 \\
255-liter refrigerator with 19 liters freezer up & 74.3 \\
home Vacuum cleaner & 17 \\
$12,000 \mathrm{Btu} / \mathrm{hr}$ split A/C & 74.3 \\
16 liters microwave oven & 28.5 \\
40L built-in electrical oven & 112 \\
\hline
\end{tabular}

Table 5. The Annual energy saving for different appliances.

\begin{tabular}{ccc}
\hline Appliance type & $\begin{array}{c}\text { Annual Energy saving } \\
(\mathrm{kWh})\end{array}$ & $\begin{array}{c}\text { Annual energy saving (\$) } \\
(1)\end{array}$ \\
\hline 8 Kg washing and spin machine* & 223 & 35.7 \\
255-liter refrigerator with 19 liters freezer up & 184.8 & 29.6 \\
home Vacuum cleaner & 40.97 & 6.5 \\
12,000 Btu/hr split air conditioner & 519.4 & 83 \\
16 liters microwave oven & 57 & 9 \\
40 liters built in electrical oven & 152.5 & 24.4 \\
\hline
\end{tabular}

Cost of $1 \mathrm{kWh}$ is $0.16 \$$.

Table 6. The S.P.B.P of using H.E instead standard appliances.

\begin{tabular}{cc}
\hline Appliance type & S.P.B.P (year) \\
\hline 8 Kg washing and spin machine & 2.8 \\
255 -liter refrigerator with 19 liters freezer up & 2.5 \\
home Vacuum cleaner & 2.6 \\
$12,000 \mathrm{Btu} / \mathrm{hr}$ split air conditioner & 0.89 \\
16 liters microwave oven & 3 \\
40 liters built in electrical oven & 4.6 \\
\hline
\end{tabular}

The SPBP for most of H.E. Appliances is less than 3-year, therefore its very feasible in Palestinian market.

According to 2017 population statistics report issued by Palestine central bureau of statistics [18], it shows the number of families and number of using appliances, the results shown in Table 7.

According to the results of survey on 300 families, the percent of using non-efficient appliances in Palestinian above families is shown in Table 8.

If the mentioned quantities for these types of appliances replaced to H.E appliances then the energy conservation and the cost saved will be as mentioned in Table 9.

\subsection{Environmental Impact}

In addition to the evaluation economic impact of implementing H.E. appliances, 
Table 7. Number of families using different appliances.

\begin{tabular}{cc}
\hline Household appliance & Number of families \\
\hline Refrigerators & 836,071 \\
Washing machine & 815,744 \\
Split air conditioner & 208,515 \\
Vacuum cleaner & 342,716 \\
Gas/electrical oven & 846,369 \\
Microwave oven & 303,472 \\
\hline
\end{tabular}

Table 8. Percentage of standard and low efficient appliances in Palestine.

\begin{tabular}{ccc}
\hline Appliance type & \% of class D, E, F, G, no label & Amount of the appliances (unit) \\
\hline Washing machine & 35 & 285,510 \\
Refrigerator & 42 & 351,150 \\
Air conditioner & 64 & 133,450 \\
Microwave oven & 91 & 277,677 \\
Electrical oven & 81 & 685,559
\end{tabular}

Table 9. The amount of energy and money saved if using H.E appliance instead of standard and non-efficient in Palestine.

\begin{tabular}{ccc}
\hline Appliance & Annual Energy conserved (kWh) & Annual Cost saved (\$) \\
\hline Washing machine & $63,668,730$ & $10,186,997$ \\
Refrigerator & $64,892,520$ & $10,382,803$ \\
Air conditioner & $69,313,930$ & $11,090,229$ \\
Microwave oven & $15,827,589$ & $2,532,414$ \\
Electrical oven & $104,547,747$ & $16,727,639$ \\
Total saving & & $50,920,082$ \\
\hline
\end{tabular}

Table 10. The reduced amount of $\mathrm{CO}_{2}$ at national level if using H.E appliances instead of standard appliances.

\begin{tabular}{cc}
\hline Appliance & Annual reduction of $\mathrm{CO}_{2}(\mathrm{Kg})$ \\
\hline Washing machine & $47,751,547.5$ \\
Refrigerator & $48,669,390$ \\
Air conditioner & $51,985,447.5$ \\
Microwave oven & $11,870,691.7$ \\
Electrical oven & $78,410,810.2$ \\
Total reduction & $238,687,886.9$ \\
\hline
\end{tabular}

the environmental impacts represented by $\mathrm{CO} 2$ emission, due to reduction of electricity generation, can be calculated and the results shown in Table 10. 


\section{Conclusion}

The objective of this research was to investigate potential of energy saving through implementing high efficient appliances in order to reduce energy consumption in different sectors in Palestine. Typically, the household energy consumption in West Bank-Palestine varies from 2400 to 48,000 kWh/year with an average value of $3600 \mathrm{kWh} /$ year, it was found that the most influence saving activities considerably decreased energy consumption in households and other commercial sectors are the use of high efficient appliances "category A of appliances". Such activities are saving power demand, saving energy consumption and these appliances account for reduced energy bills in different sectors as well as having long operating hours. Also, this has enhanced consumers to maintain a clean environment. The initial installation of energy efficient appliances may be expensive, but the overall benefits of a consumer at large are feasible in the long run, the S.P.B.P for most of appliances around 3 years. The results of this preliminary study will be further used to encourage decision makers to implement new standards and H.E. Labels for Palestinian market, the national benefits will be very high economically and environmentally.

\section{Conflicts of Interest}

The authors declare no conflicts of interest regarding the publication of this paper.

\section{References}

[1] Energy Charter Secretariat (2009) Introducing Energy Efficiency Standards and Labels for Appliances and Equipment. Boulevard de la Woluwe, Brussels, Belgium.

[2] United States Environmental Protection Agency (2003) Energy Star The Power to Protect the Environment through Energy Efficiency. United States Environmental Protection Agency Air and Radiation.

[3] Word Bank Group (2016) West Bank \& Gaza Energy Efficiency Action Plan 2020-2030, Report.

[4] La Rue du Ca, S., Leventis, G., Phadke, A. and Gopal, A. (2014) Design of Incentive Programs for Accelerating Penetration of Energy-Efficient Appliances. Energy Policy, 72, 56-66. https://doi.org/10.1016/j.enpol.2014.04.035

[5] Ibrik, I. and Hashaika, F. (2019) Techno-Economic Impact of Grid-Connected Rooftop Solar Photovoltaic System for Schools in Palestine: A Case Study of Three Schools. International Journal of Energy Economics and Policy, 9, 291-300. https://doi.org/10.32479/ijeep.7593

[6] Ibrik, I. (2019) Modeling the Optimum Solar PV System for Management of Peak Demand. International Journal of Energy Economics and Policy, 9, 246-250.

[7] Ibrik, I.H. (2019) An Overview of Electrification Rural Areas in Palestine by Using Micro-Grid Solar Energy. Journal Cogent Engineering, 6, Article ID: 1638574. https://doi.org/10.1080/23311916.2019.1638574

[8] Ibrik, I.H. and Mahmoud, M.M. (2002) Energy Efficiency Improvement by Raising of Power Factor at Industrial Sector in Palestine. Journal of Applied Sciences, 2, 907-312. https://doi.org/10.3923/jas.2002.907.911 
[9] International Energy Agency (2015) International Energy Agency Report.

[10] Kama, Ö. and Kaplan, Z. (2013) Energy Efficiency Policies in Turkey: The Case for Standards and Labels. International Journal of Energy Economics and Policy, 3, 62-73.

[11] Abd Alfattah, A., Sakhrieh, A. and Al-Ghandoor, A. (2017) Energy Efficiency Standards and Labels for Cold Appliances in Jordan. International Journal of Energy Economics and Policy, 7, 95-101.

[12] Ahmed, A.S., Hamdan, S. and Syed Shazali, S.T. (2011) Electricity Savings by Implementing Energy Efficiency Standards and Labels for Clothes Washers in Malaysia. Journal of Engineering Science and Technology, 6, 29-38.

[13] Covary, T., Du Preez, K. and Götz, T. (2013) Energy Efficient Ovens, Appliances Guide Get Super-Efficient Appliances, South Africa.

[14] Harrington, L. and Damnics, M. (2004) Energy Labeling and Standards Programs throughout the World. The National Appliance and Equipment Energy Efficiency Committee, Australia.

[15] ANEC (2015) Simplifying the EU Energy Label Restoring the Successful and Well-Understood Closed A to G Scheme.

[16] Udasin, S. (2012) Replacement of Inefficient Air Conditioners Begins. https://www.jpost.com/Enviro-Tech/Replacement-of-inefficient-air-conditioners-be gins

[17] Arabic-Islamic States (1995) The Israeli-Palestinian Interim Agreement on the West Bank and Gaza Strip. Protocol on Economic Relations between Government of Israel and P.L.O, Paris, 09.04.1994.

[18] Palestinian Central Bureau of Statistics (2017) Census of Population, Housing and Establishments. 